\title{
POSTOPERATIVE COMPLICATIONS OF SUCTION DRAIN IN PATIENTS SUBMITTED TO 1-LEVEL LUMBAR ARTHRODESIS
}

\author{
COMPLICAÇÕES PÓS-OPERATÓRIA DO DRENO DE SUCÇÃO EM PACIENTES SUBMETIDOS \\ A ARTRODESE LOMBAR DE UM NIVEL
}

\author{
COMPLICACIONES POSTOPERATÓRIO DEL DRENO DE SUCCIÓN EN PACIENTES \\ SOMETIDOS A ARTRODESIS LUMBAR DE UN NIVEL
}

\author{
Marcus Alexandre Novo Brazolino ${ }^{1}$, Charbel Jacob Júnior ${ }^{1}$, Igor Machado Cardoso ${ }^{1}$, José Lucas Batista Júnior ${ }^{1}$, Thiago Cardoso Maia1, \\ Tadeu Gervazon Debom ${ }^{1}$, Bruno Rocanglio \\ 1. Hospital Santa Casa de Misericórdia de Vitória. Orthopedics andTraumatology Service, Vitória, ES, Brazil.
}

\begin{abstract}
Objective: To evaluate the complications inherent in the use or not of continuous suction drain in postoperative period of patients undergoing 1-level lumbar arthrodesis. Methods: An analytical, comparative, randomized study was performed with a sample of 60 patients submitted to 1-level $360^{\circ}$ lumbar arthrodesis with TLIF technique, 30 of whom used the suction drain for three days after surgery and another 30 did not use the suction drain in the postoperative period. The complications that occurred on the 3rd, 14th, and 28th postoperative days of patients of both groups and the Visual Analog Scale for pain were evaluated and compared. The complications assessed were seroma, superficial infection and suture dehiscence. Results: A total of $23.3 \%$ surgical wound complications were found, the most frequent being seroma (16\%). In total, each group presented seven complications. There were no statistical differences observed in the evaluation of seroma, infection, wound dehiscence on the 3rd, 14th, and 28th postoperative days in both groups. Conclusion: The use or not of suction drain in 1-level lumbar surgeries does not interfere with complications such as seroma, infection, and suture dehiscence.
\end{abstract}

Keywords: Arthrodesis; Spine; Spine fusion; Seroma; Surgical wound dehiscence; Infection.

\section{RESUMO}

Objetivo: Avaliar as complicações inerentes à utilização ou não de dreno de sucção contínua em pós-operatório de pacientes submetidos a artrodese lombar de um nível. Métodos: Estudo analítico, comparativo, randomizado, com uma amostra de 60 pacientes submetidos a artrodese lombar de $360^{\circ}$ em um nível com técnica TLIF, sendo que 30 utilizaram o dreno de sucção por três dias no pós-operatório e outros 30 não utilizaram o dreno de sucção no pós-operatório. Foram avaliadas e comparadas as complicações surgidas no $3^{\circ}, 14^{\circ}$ e $28^{\circ}$ dias pós-operatório dos pacientes de ambos os grupos e a Escala Visual Analógica para dor. As complicações avaliadas foram seroma, infecção superficial e deiscência de sutura. Resultados: Encontrou-se um total de 23,3\% de complicações da ferida cirúrgica, sendo a mais frequente o seroma (16\%). No total das complicações cada grupo apresentou sete. Não foram observadas diferenças estatísticas na avaliação de seroma, infecção, deiscência de sutura no $3^{\circ}, 14^{\circ}$ e $28^{\circ}$ dia de pós-operatório em ambos os grupos. Conclusão: $A$ utilização ou não de dreno de sucção em cirurgias lombares em um nível não interfere no surgimento das complicações como seroma, infecção e deiscência de sutura.

Descritores: Artrodese; Coluna vertebral; Fusão vertebral; Seroma; Deiscência da ferida operatória; Infecção.

\section{RESUMEN}

Objetivo: Evaluar las complicaciones inherentes a la utilización o no de drenaje de succión continua en el postoperatorio de pacientes sometidos a artrodesis lumbar de un nivel. Métodos: Estudio analítico, comparativo, aleatorizado, con una muestra de 60 pacientes sometidos a artrodesis lumbar de $360^{\circ}$ de un nivel con técnica TLIF, siendo que 30 utilizaron el drenaje de succión por tres días en el postoperatorio y otros 30 no utilizaron el drenaje en el postoperatorio. Se evaluaron y compararon las complicaciones surgidas en los días 3, 14 y 28 de días del postoperatorio de los pacientes en ambos grupos y la escala analógica visual para el dolor. Las complicaciones evaluadas fueron seroma, infección superficial y dehiscencia de sutura. Resultados: Se encontró un total de 23,3\% de complicaciones de la herida quirúrgica, siendo el seroma la más frecuente (16\%). En el total de las complicaciones cada grupo presentó siete. No se observaron diferencias estadísticas en la evaluación de seroma, infección, dehiscencia de sutura en el $3^{\circ}, 14^{\circ}$ y $28^{\circ}$ día de postoperatorio en ambos grupos. Conclusión: El uso o no de drenaje de succión en cirugías lumbares de un nivel no interfiere en la aparición de complicaciones como seroma, infección y dehiscencia de sutura.

Descriptores: Artrodesis; Columna vertebral; Fusión vertebral; Seroma; Dehiscencia de la herida operatoria; Infección. 


\section{INTRODUCTION}

Arthrodesis is performed extensively in the surgical treatment of several vertebral pathologies and its indication has increased exponentially over the last two decades. ${ }^{1,2}$ It is indicated mainly in cases of lumbosciatalgia refractory to conservative treatment associated with signs of instability evidenced in dynamic radiographs or of collapse of disc space observed in magnetic resonance, ${ }^{3-5}$ with the goal of relieving pain caused by degenerative diseases. ${ }^{3}$

Currently, the most frequently used vertebral arthrodesis technique is interbody arthrodesis, which consists of both posterior and anterior fusion, thus increasing the rate of vertebral fusion. Although this technique is the one with the best clinical results and is the most used, it is not exempt from complications such as infection, seroma, neurological damage, and pseudoarthrosis, among others. ${ }^{6-9}$

A suction drain is used in these surgeries for the aspiration of third-space collections in order to prevent the formation of seromas and hematomas. ${ }^{10,11}$ On the other hand, using the drain can cause postoperative pain, anxiety, and discomfort in these patients. ${ }^{12}$ There is no consensus around the increase or decrease of infection with its use. The drain can cause local inflammatory processes in reaction to a foreign body and to increase local defense. Similarly, it can predispose the patient to local infection because of contact between the internal and external environments. ${ }^{13}$

The objective of this study was to analyze the possible complications inherent in the use or not of a suction drain in patients submitted to $360^{\circ}$ single-level lumbar arthrodesis using the TLIF (Transforaminal Lumbar Interbody Fusion) open interbody arthrodesis technique.

\section{METHODS}

This was a prospective, randomized study approved by the Institutional Review Board of the EMESCAM (protocol 005/2012). The patients underwent decompression associated with posterior-lateral interbody arthrodesis at one level using the open TLIF technique and were knowledgeable about the project through the informed consent form.

The number of patients evaluated was 60 , divided into 30 patients submitted to use of the suction drain and 30 patients without its use. This number was not determined by statistical analysis. In the preoperative period, the VAS (Visual Analog Scale) for pain radiating to the lower limbs was evaluated by age and sex, and randomization was conducted just prior to the surgical procedure by a lottery performed by a member of the surgical team who was not among the authors of this study. There were 60 cards in an urn, 30 with the number one and 30 with the number two. The suction drain was not used for the patients in group one (ND), while it was used for the patients in group two (YD).

In the postoperative period, the Visual Analog Scale (VAS) for pain radiating to the lower members and the presence of complications at the surgical site, such as seroma, superficial infection, and dehiscence of the surgical wound, were evaluated on the 3rd, 14th, and 28th days following surgery. The drains were removed from the patients in the YD group on the 3rd day following surgery. For the management of postoperative pain, standard analgesia was administered to all patients with analgesics, anti-inflammatory medications, and opioids. Prophylactic antibiotics (Cefazolin $2 \mathrm{~g}$ ) were administered only by anesthetic induction.

The inclusion criteria were symptomatic patients with lumbar pathologies such as lumbar canal stenosis, listhesis, and disc herniation, all refractory to conservative treatment. All the patients presented lumbar pathologies that required a single-level surgical approach.

The exclusion criteria were patients who needed arthrodesis in more than one level, arthrodesis in other vertebral segments, or with the presence of previous lumbar surgeries, tumors, fractures, and patients with allergies to the standard analgesic medications used postoperatively.

The statistical analyses were conducted using SPSS $\AA$ version 23.0 software. The statistical inference was adopted at a level of significance of $5 \%(p<0.05)$. Fisher's test was applied to analysis the index of postoperative complications of each group and the Mann Whitney test was used to analyze postoperative pain in each group on the 3rd, 14th, and 28th days following surgery for evaluating the median of the samples.

\section{RESULTS}

We evaluated 60 patients, 30 of whom were YD (averaging 53.3 years of age) and 30 or whom were ND (averaging 48 years of age). We encountered 14 postoperative complications of the surgical wound, the most frequent being seroma. One early surgical intervention was necessary for deep cleaning associated with antibiotic therapy as a result of infection in one patient in the with drain group. Oral antibiotics were administered to the other patients with superficial infection with clinical improvement.

\section{Evaluation of seroma}

Seroma was present from the 3rd postoperative day in the without drain group (four patients) and was not observed in the with drain group $(p=0.112)$.

On the 14th day, the YD group presented 5 patients with seroma and one new case appeared in the ND group. In the ND group, 2 were cured and three others remained with seroma. There was no statistical significance between the groups $(p=0.706)$.

On the 28th day, the seroma was resolved in three patients in the YD group, while two cases pre-existing from the 14th day following surgery persisted. One patient in ND persisted with seroma on the 28th day. There was no statistical significance between the two groups $(p=1.0)$. (Figure 1)

\section{Evaluation of dehiscence}

There was one case of suture dehiscence in the without drain group on the 28th day. However, it was not statistically significant $(p=1.0)$. (Figure 2$)$

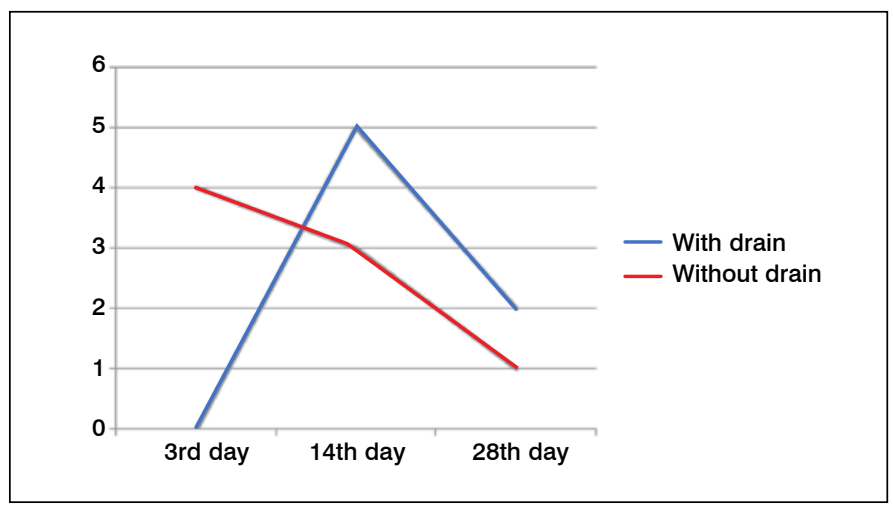

Figure 1. General seroma evaluation.

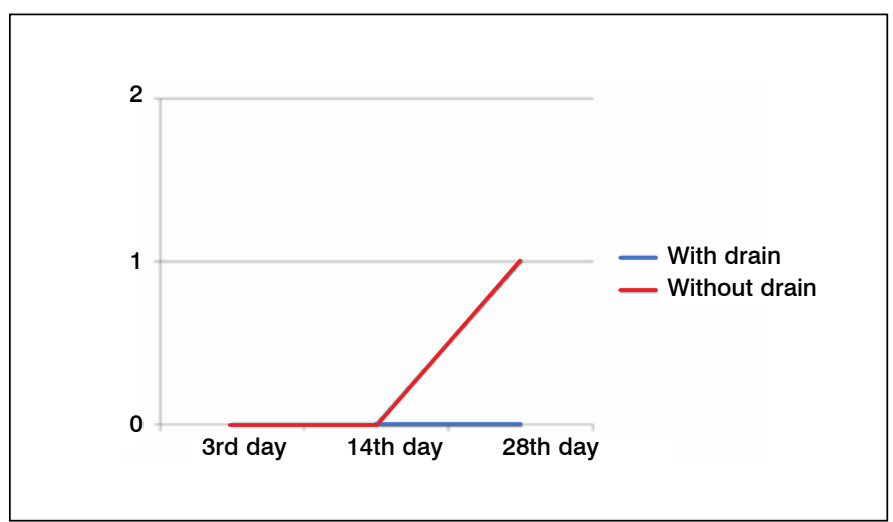

Figure 2. General evaluation of suture dehiscence. 


\section{Evaluation of infection}

There were three cases of infection in the postoperative period, corresponding to $5 \%$ of all the cases operated.

The infection occurred starting from the 14th day following surgery with two cases in the YD group and one case in the ND group $(p=1.0)$. (Table 1) There was 1 deep infection in the with drain group, and debridement and early surgical cleaning, without removal of the arthrodesis material, associated with two weeks of intravenous antibiotic therapy. The other cases were superficial infections and antibiotic therapy was administered with improvement of symptoms after two weeks without the removal of the arthrodesis material.

On the 28th day, one patient in each group tested as cured from infection after administration of oral antibiotics starting on the 14th day of reevaluation and infection persisted in one patient in the YD group. The statistical relationship of both groups was not significant $(p=1.0)$. (Figure 3$)$

\section{Evaluation of the visual analog scale, pain}

There was no statistical significance between the groups at any of the periods (3rd, 14th, and 28th days) evaluated. (Table 2)

Table 1. Infection on the 14th postoperative day.

\begin{tabular}{|c|c|c|c|c|c|}
\hline & & & \multicolumn{2}{|c|}{ Group } & \multirow{2}{*}{ Total } \\
\hline & & & Without drain & With drain & \\
\hline \multirow{4}{*}{$\begin{array}{l}\text { Infection } \\
\text { day } 14\end{array}$} & \multirow{2}{*}{ No } & Count & 29 & 28 & 57 \\
\hline & & $\%$ of Total & $48.3 \%$ & $46.7 \%$ & $95.0 \%$ \\
\hline & \multirow{2}{*}{ Yes } & Count & 1 & 2 & 3 \\
\hline & & $\%$ of Total & $1.7 \%$ & $3.3 \%$ & $5.0 \%$ \\
\hline \multirow{2}{*}{\multicolumn{2}{|c|}{ Total }} & Count & 30 & 30 & 60 \\
\hline & & $\%$ of Total & $50.0 \%$ & $50.0 \%$ & $100.0 \%$ \\
\hline
\end{tabular}

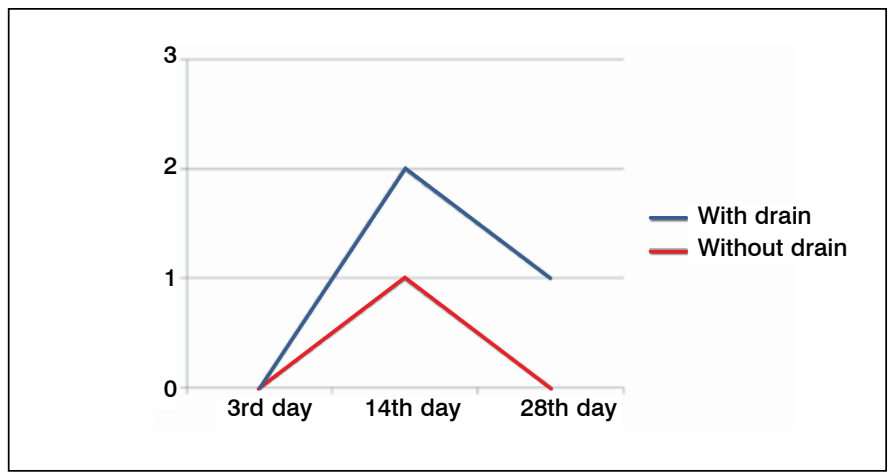

Figure 3. General evaluation of infection.

Table 2. Median VAS in all periods.

\begin{tabular}{c|c|c|c}
\hline \multirow{2}{*}{ VAS } & Without drain & With drain & \\
\cline { 2 - 4 } & Median (01 - 03) & Median (01 - 03) & $\mathbf{p}$ \\
\hline Pre-op & $9(8-10)$ & $9(8-10)$ & 0.313 \\
\hline 3rd day & $0(0-2)$ & $1(0-2)$ & 0.498 \\
\hline 14th day & $0(0-1)$ & $0(0-0)$ & 0.109 \\
\hline 28th day & $0(0-0)$ & $0(0-0)$ & 0.300 \\
\hline
\end{tabular}

\section{DISCUSSION}

Traditionally, a drain is used in spine surgeries to prevent postoperative complications such as epidural hematomas. ${ }^{13}$ In this study, we sought to evaluate the influence of the use of a suction drain in the treatment of single-level lumbar surgeries with possible postoperative complications such as seroma, dehiscence, local infection, and pain.
TLIF is an intervertebral fusion technique in which the approach to the intervertebral space occurs through the intervertebral foramen. ${ }^{14}$ Degenerative spine diseases commonly evolve with reduced intervertebral disc height and foraminal stenosis at the affected level. ${ }^{15}$ The use of TLIF provides gains in disc height, increased lumbar lordosis, indirect decompression of the neural foramen, and lower incidence of pseudoarthrosis. ${ }^{16}$ Thus, it is widely used in our field.

Infection of the surgical site is one of the most commonly observed complications in spine surgery, occurring in $2.2 \%$ to $8.5 \%$ of cases where instrumentation is required. ${ }^{17,18}$ Some studies have shown procedure infection rates that reach as high as 20\%. ${ }^{19}$

In this study we observed infection in 5\% (two superficial and one deep) of the total number of surgeries performed, two recorded in the group using a drain and one in the group not using a drain, with the beginnings of this complication seen on the 14th day after surgery. Deep infection was seen in one patient in the with drain group. There was no statistical difference in the development of infection in the comparison between the groups, which represented neither benefit nor harm with the use of the suction drain. This finding is consistent with that evidenced by Waly, who observed postoperative infection rates in patients with degenerative lumbar disease of $7.1 \%$ in with drain patients and $7.3 \%$ in without drain patients. ${ }^{20}$

The formation of seroma is defined as any clinical evaluation of fluid collection that requires local aspiration. ${ }^{21}$ According to Reiffel et al., ${ }^{22}$ there is no significant difference in seroma formation between groups with the use or not of suction drains, but there is a higher incidence in the with drain group as a result of the inflammatory process caused in reaction to a foreign body.

In our study, the with suction drain group had a greater propensity for seroma formation in the immediate postoperative period (3rd day following surgery). At the end of the 28th day following surgery, both groups had the same number of patients with seroma in the surgical wound and there was no significant difference in any of the periods analyzed. This shows that the use of a suction drain did not influence the final result in the formation of seroma.

According to Wong et al., ${ }^{23}$ the utilization of the open TLIF technique as a surgical approach presents an average VAS score for leg pain of 1.3 one year following surgery. According to Parker et al., ${ }^{24}$ the average VAS score was 2.7 two years after the surgical procedure.

In our study, the average VAS score for pain in the lower limbs in the 4-week postoperative evaluation was 0.2 for the with drain group and 0.5 for the without drain group. Comparative studies show an average VAS higher than that found in this study, possibly related to the longer evaluation period as compared to this study since the significant improvement immediately following the procedure may inflate the results, making a longer follow-up necessary to determine the VAS score.

In this study, there was no significant difference in relation to postoperative pain between the groups observed in any of the periods analyzed, which indicates that the use or not of the drain does not interfere in the increase or reduction of pain.

A limitation found in this study is the initial statistical evaluation of the size of the sample for each group, which can generate false-negative results since a sample calculation was not performed to determine the number of patients in each group.

\section{CONCLUSIONS}

Patients who underwent decompression and one-level lumbar arthrodesis presented no difference in terms of the use of a suction drain and the appearance of complications such as infection, dehiscence of the sutures, low back pain, or seroma.

All authors declare no potential conflict of interest related to this article. 
CONTRIBUTION OF THE AUTHORS: Each author made significant individual contributions to this manuscript. Concept and study design: MANB and CJJ. Data acquisition and IRB approval: MANB. Analysis and interpretation of the data: MANB, CJJ, IMC. Development of the article: MAN, TGD, TCM, BR. Critical review of the article: MANB. Review of the final version for submission: MANB, CJJ, IMC, JLBJ, TCM, TGD, BR.

\section{REFERENCES}

1. Olivares LMR, Vaca JC, Martínes VPM, Aguirre AA, Reyes-Sánches AA. Desarrollo de enfermedad del segmento adyacente en arthrodesis circunferencial lumbar: cuatro años de seguimiento. Coluna/Columna. 2006;5(1):7-14.

2. Gillet P. The fate of the adjacent motion segments after lumbar fusion. J Spinal Disord Tech. 2003;16(4):338-45.

3. Vaccaro AR, Betz RR, Zeidman SM. Cirurgia da coluna: princípios e prática. 2nd ed. Rio de Janeiro: Di Livros; 2007.

4. Avanzi O, Chih LY, Meves R, Silber MF. Tratamento da instabilidade lombar com parafusos pediculares. Acta Ortop Bras. 2005;13(1):5-8.

5. Kim TY, Kang KT, Yoon DH, Shin HC, Kim KN, Yi S, et al. Effects of lumbar arthrodesis on adjacent segments: differences between surgical techniques. Spine (Phila Pa 1976). 2012;37(17):1456-62.

6. Di Lauro L, Poli R, Bortoluzzi M, Marini G. Paresthesias after lumbar disc removal and their relationship to epidural hematoma. Report of two cases. J Neurosurg. 1982:57(1):135-6.

7. Lawton MT, Porter RW, Heiserman JE, Jacobowitz R, Sonntag VK, Dickman CA. Surgical management of spinal epidural hematoma: relationship between surgical timing and neurological outcome. J Neurosurg. 1995:83(1):1-7.

8. Morse K, Weight M, Molinari R. Extensive postoperative epidural hematoma after full anticoagulation: case report and review of the literature. J Spinal Cord Med. 2007;30(3):282-7.

9. Koutsoumbelis S, Hughes AP, Girardi FP, Cammisa FP Jr, Finerty EA, Nguyen JT, et al. Risk factors for postoperative infection following posterior lumbar instrumented arthrodesis. J Bone Joint Surg Am. 2011;93(17):1627-33.

10. Bachoura A, GuittonTG, Smith RM, Vrahas MS, Zurakowski D, Ring D. Infirmity and injury complexity are risk factors for surgical-site infection after operative fracture care. Clin Orthop Relat Res. 2011;469(9):2621-30.

11. Derksen WJ, Verhoeven BA, van de Mortel RH, Moll FL, de Vries JP. Risk factors for surgical-site infection following common femoral artery endarterectomy. Vasc Endovascular Surg. 2009;43(1):69-75

12. Sangrasi AK, Leghari AA, Memon A, Talpur AK, Qureshi GA, Memon JM. Surgical site infection rate and associated risk factors in elective general surgery at a public sector medical university in Pakistan. Int Wound J. 2008:5(1):74-8.

13. Brown MD, Brookfield KF. A randomized study of closed wound suction drainage for extensive lumbar spine surgery. Spine (Phila Pa 1976). 2004;29(10):1066-8.
14. Cole CD, McCall TD, Schmidt MH, Dailey AT. Comparison of low back fusion techniques: transforaminal lumbar interbody fusion (TLIF) or posterior lumbar interbody fusion (PLIF) approaches. Curr Rev Musculoskelet Med. 2009;2(2):118-26.

15. Herkowitz HN. Degenerative lumbar spondylolisthesis: evolution of surgical management. Spine J. 2009;9(7):605-6.

16. Kepler CK, Rihn JA, Radcliff KE, Patel AA, Anderson DG, Vaccaro AR, et al. Restoration of lordosis and disk height after single-level transforaminal lumbar interbody fusion. Orthop Surg. 2012:4(1):15-20.

17. Collins I, Wilson-MacDonald J, Chami G, Burgoyne W, Vineyakam P, Berendt T, et al. The diagnosis and management of infection following instrumented spinal fusion. Eur Spine J. 2008;17(3):445-50.

18. Schimmel JJ, Horsting PP, de Kleuver M, Wonders G, van Limbeek J. Risk factors for deep surgical site infections after spinal fusion. Eur Spine J. 2010;19(10):1711-9.

19. Rickert $M$, Schleicher P, Fleege C, Arabmotlagh M, Rauschmann M, Geiger F, et al. Management of postoperative wound infections following spine surgery: First results of a multicenter study. Orthopade. 2016;45(9):780-8.

20. Waly F, Alzahrani MM, Abduljabbar FH, Landry T, Ouellet J, Moran K, et al. The outcome of using closed suction wound drains in patients undergoing lumbar spine surgery: a systematic review. Global Spine J. 2015;5(6):479-85.

21. Dalberg K, Johansson H, Signomklao T, Rutqvist LE, Bergkvist L, Frisell J, et al. A randomised study of axillary drainage and pectoral fascia preservation after mastectomy for breast cancer. Eur J Surg Oncol. 2004;30(6):602-9.

22. Reiffel AJ, Barie PS, Spector JA. A multi-disciplinary review of the potential association between closed-suction drains and surgical site infection. Surg Infect (Larchmt). 2013;14(3):244-69

23. Wong AP, Smith ZA, Stadler JA 3rd, Hu XY, Yan JZ, Li XF, et al. Minimally invasive transforaminal lumbar interbody fusion (MI-TLIF): surgical technique, long-term 4-year prospective outcomes, and complications compared with an open TLIF cohort. Neurosurg Clin N Am. 2014;25(2):279-304.

24. Parker SL, Mendenhall SK, Shau DN, Zuckerman SL, Godil SS, Cheng JS, et al. Minimally invasive versus open transforaminal lumbar interbody fusion for degenerative spondylolisthesis: comparative effectiveness and cost-utility analysis. World Neurosurg. 2014;82(1-2):230-8. 